http://dx.doi.org/10.4314/jae.v17i1.16

\title{
Use of Information and Communication Technologies among Extension Agents In Kano State, Nigeria
}

\author{
Yakubu, D.H', B.Z. Abubakar ${ }^{1}$, T.K. Atala ${ }^{2}$ and A. Muhammed ${ }^{3}$ \\ ${ }^{1}$ Department of Agricultural Extension and Rural Development, \\ Usmanu Danfodiyo University, Sokoto. \\ ${ }^{2}$ Department of Agricultural Economics and Rural Sociology, \\ Ahmadu Bello University, Zaria. \\ ${ }^{3}$ Department of Mathematics, \\ Usmanu Danfodiyo University, Sokoto. \\ Corresponding author: danlami y@yahoo.com +234(0)8069064617; +234(0)8057234043
}

\begin{abstract}
The study assessed the use of ICTs among extension agents in Kano State Nigeria. Two hundred and twenty-one (221) extension agents were randomly selected from the 44 local government areas. Data for the study were obtained with the aid of structured questionnaire administered to extension agents. Majority of extension agents were in the age range of 41-50 years. Majority (87.3\%) of them were males and married (100\%), with family sizes of 5-14 (53.95\%). The entire extension agents had formal education including HND (35.8\%), OND (33.3\%) and secondary school certificate (27.2\%). Most of the extension agents had an annual income of $\mathbf{N 1 0 0 , 0 0 0 -}$ \#300,000, with $\mathrm{N} 376,984$ as mean. They were aware and had access to radio, television, telephone, DVD, video, camera, computer, satellite and printer. They however recorded a low usage of the Web, satellite, e-mail, CD-ROM, search engines, scanner, fax and Web publishing. The result also indicates a positive correlation between ICT use and socio-economic characteristics of the agents; including age, work experience, membership of agricultural associations $(p<0.05)$. It was concluded that the benefits of the ICTs were not fully utilized by extension workers in the state due to some factors associated with low income, ICTs training, awareness and access.
\end{abstract}

Keywords: Information, Communication, Technologies, Extension Agents

\section{Introduction}

The main purpose of agricultural extension activities is to communicate relevant and useful information to the end users in order to persuade them to adopt that which will eventually lead to increase in agricultural production. To achieve this, extension workers and their trainers should be knowledgeable and skilful in communication (Okunade and Oladosu 2006).

The use of Information and Communication Technologies (ICTs) in agriculture, just like in the other fields of knowledge, has been gaining popularity in Africa and Nigeria in particular. During the last two decades, the world witnessed an unprecedented growth in the area of ICT (Hosseini et. al., 2009). The use of conventional communication channels such as farm/home visit, personal letters, and use of contact farmers, for disseminating agricultural information is counterproductive (Arokoyo, 2005). This calls for the adoption of ICTs by both 


\section{Journal of Agricultural Extension}

Vol. 17 (1) June, 2013

ISSN 1119-944X

researchers and extension workers to transmit relevant information to farmers in a most efficient way (FAO, 1993; Salau and Saingbe, 2008).

ICTs can be broadly interpreted as technologies that facilitate communication and the processing and transition of information by electronic means. This definition encompasses the full range of ICTs from radio and television to telephones (fixed and mobile), computers and the internet (CTA, 2003). Food and Agriculture Organization (FAO, 1993) defines ICT as technologies involved in collecting, processing, storing, retrieving, disseminating and implementing data and information using microelectronics, optics and telecommunications and computers.

ICTs have the potentials of bridging the existing communication gap among the extension workers on one hand and between the extension workers and the farmers on the other. According to CTA (2003), ICTs have the potentials to enhance farmers' ability to collate demands; collaborative learning; exchange of time sensitive information e.g. market prices, disease outbreaks, etc. make extension systems and structures more efficient; engage farmers in assessing own needs, solutions; facilitating multi-stakeholder brainstorming; exploring alternative production technologies; facilitating access to markets and credits; training and demonstration; community learning; search, select and compile information for individual clients; early warning for disasters etc. and weather forecast; and peer to peer sharing and exchange among extension

If modern ICT facilities are not adequately built into the mainstream of Nigerian agricultural system, there is likely to be stagnation in the dissemination, utilization and application of scientific agricultural information for purposeful development of the system (Adebayo and Adesope, 2007). Modern agricultural extension system encourages the development of positive attitude in the scientists to appreciate the knowledge, experience and capacities of the local people in the research development process (Amalu, 1998).

It has therefore become necessary for all stakeholders to join hands in developing ICT world in Nigeria since it has the potential of transforming agriculture through agricultural extension in the country. An agricultural extension worker can learn new technologies, rainfall forecasts, commodity prices, etc and use that information to advice farmers in villages. The importance of ICTs in development process was long recognized and access to ICTs was even made one of the targets of the Millennium Development Goal No. 8 (MDG 8), which emphasizes the benefits of new technologies, especially ICTs in the fight against poverty. "With 10 percent increase in high-speed internet connections, economic growth increases by 1.3 percent" observed a World Bank report on Information and Communication for Development (World Bank, 2009). The same report also observed "connectivity - whether the Internet or mobile phones -- is increasingly bringing market information, financial services, and health services to remote areas, and is helping to change people's lives in unprecedented ways" (Asenso-Okyere and Mekonnen, 2012). ICT is therefore a veritable tool for transformation of Nigerian agriculture.

Agriculture is still the main stay of Nigerian economy, employing over $70 \%$ of the population. This is more so in the north and Kano state in particular. Agricultural extension system has the responsibility to develop the country's agriculture. Such 
development is often measured through the performance of the extension agents, whose main responsibility is to communicate innovations to the end users. However, there is no adequate information on whether the extension agents utilize the necessary ICTs in contacting the farmers, especially in Kano state.

The study was therefore designed to assess the use of ICTs among extension workers in Kano state.

\section{Objectives of the study}

The broad objective of the study was to assess the use of ICTs among extension agents in Kano state, Nigeria. The specific objectives were to examine the awareness, access and use of ICTs by the extension agents; and determine the relationship between some selected socio-economic characteristics of extension agents and ICT-use.

\section{Methodology}

The study was conducted in Kano state, northern Nigeria. The state has 44 local government areas, lies between latitudes $10^{\circ} 33^{\prime} \mathrm{N}$ and $12^{\circ} 37^{\prime} \mathrm{N}$ and longitudes $7^{0}$ $34^{\prime} \mathrm{E}$ and $9^{0} 29^{\prime} \mathrm{E}$ (Yakubu, 2011). The total land area is estimated at 20,760 square kilometres while the population is 9, 383,682 inhabitants who are mainly Hausa/Fulani and $80 \%$ of them engaged in farming (NPC, 2006). Most part of the state lies within the Sudan Savannah vegetation zone. On some parts of the western and southern boundaries, some traces of Guinea Savannah exists (KNSG, 2004).

The target population for the study was the entire extension agents under the Kano Agricultural and Rural Development Authority (KNARDA). Simple random sampling technique was used to proportionately select extension agents from each of the 3 zones of KNARDA in the state. A total of 221 extension agents were selected.

Structured questionnaire was administered to the extension agents to obtain data on socio-economic characteristics of the extension agents and awareness, access and use of ICTs.

Data were subjected to descriptive and inferential statistical analyses. Objectives one and two were analyzed using frequency and percentage while objective three was analysed using Pearson product- moment correlation to determine the relationship between the selected socio-economic characteristics and level of ICTuse.

\section{Measurement of Variables}

The study considered two sets of variables; dependent and independent variables. The dependent variable $Y$ is ICT use. The study referred to the following ICTs: Radio, Television, Telephone (fixed and mobile), The Web, Search Engines, Packet digital Assistants, Cameras, Videos, E-mail, Computer, Scanner, CD-ROM, DVD, Satellite, Fax, Printer and Web Publishing. 


\section{Journal of Agricultural Extension}

Vol. 17 (1) June, 2013

ISSN 1119-944X

Depending on the number of ICTs used by extension workers, ICT use was trichotomized into low (when < 9 ICTs were used), medium (when 9-12 ICTs were used) and high (when >12 ICTs were used).

The most important independent variables were measured as follows:

Age: In years.

Education: Measured according to the level of formal education attained $(2=$ secondary; $3=$ OND; 4 = HND; $5=$ B. Sc./B.A; $6=$ M. Sc./M.A and $7=$ PhD).

Work experience: Measured in the number of years spent working.

Annual income: Measured in $\$$ /year.

Membership of agricultural associations: Dichotomized into members and nonmembers.

Training on ICT Received: Categorized into no training and received training.

Awareness of ICTs: Measured in the number of ICTs extension worker is aware of.

Access to the ICTs: Also measured in the number of ICTs extension worker had access to.

\section{Results and discussion \\ Socio-economic Characteristics of the Extension agents}

Result on Table 1 shows that $49.8 \%$ of the respondents were within the ages of 41 50 years and only $16.3 \%$ were within $21-30$ years. The mean age was 40.6 years. This indicates that most of the extension agents were in their middle ages and are therefore old enough to take decision on the use of ICTs.

Majority (87.3\%) of the extension agents were males (Table 1$)$. This indicates that the extension agents in were predominantly males. This may be connected with gender disparity found in the public service in Nigeria. It also agrees with Adedoyin et al (1999) who reported that males dominated the agricultural workforce in Nigeria. It further implies that technology development and transfer will be gender biased (Salau and Saingbe, 2008).

Table 1 also shows that the entire (100\%) extension agents were married. It further shows that majority (53.9\%) of them had family sizes in the range of 5-14. This implies that the extension agents have family responsibilities which might negatively affect their ability to purchase or employ the services of the ICTs.

Table 1 reveals that $35.8 \%$ of the extension agents had Higher National Diploma (HND), 33\% had Ordinary National Diploma (OND), 27.2\% had Secondary School Certificate and $3.6 \%$ had a Bachelor Degree (B. Sc or B. A) as their highest educational level attained. This indicates that the entire respondents had one educational qualification or the other. They were therefore literates and could utilize ICTs to improve their work as change agents. Majority $(52.9 \%)$ of the extension agents had a working experience of 15-20 years. It indicates that most of the extension agents were over 15 years in the service. Such years of experience could enable the extension agent to save enough money to purchase the ICT facilities.

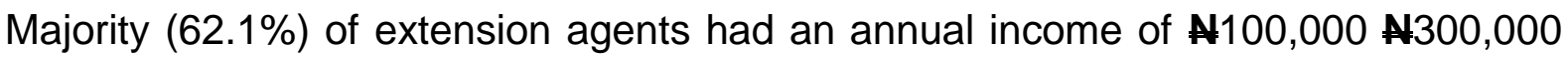
while $20.4 \%$ had $\mathbf{N} 301,000 \mathbf{N 5 0 0 , 0 0 0}$. The mean annual income was $\mathbf{N} 376,984$ $(\$ 2,313)$ that is about $\mathbf{N 1 , 4 1 5}(\$ 192)$ per month. This reveals that the extension 


\section{Journal of Agricultural Extension}

Vol. 17 (1) June, 2013

ISSN 1119-944X

workers were not comfortable enough financially to acquire and maintain most of the ICTs, especially computers and their accessories and mobile phones. Salau and Saingbe (2008), discovered that extension workers in Nassarawa state, Njgeria earned below N61,000 monthly which led to their lower level of ICTs utilization compared to agricultural researchers in the area. Poverty has also been observed by Arokoyo (2005) as a major constraint to ICT utilization.

Table 1

Socio-economic Characteristics of the Extension agents $(n=221)$

\begin{tabular}{|c|c|c|}
\hline Variables & Frequency & Percentage \\
\hline \multicolumn{3}{|l|}{ Age (years) } \\
\hline $21-30$ & 36 & 16.3 \\
\hline $31-40$ & 63 & 28.5 \\
\hline $41-50$ & 110 & 49.8 \\
\hline $51-60$ & 12 & 5.4 \\
\hline \multicolumn{3}{|l|}{ Mean age $=40.6$ years } \\
\hline \multicolumn{3}{|l|}{ Sex } \\
\hline Male & 193 & 87.3 \\
\hline Female & 28 & 12.7 \\
\hline \multicolumn{3}{|l|}{ Marital Status } \\
\hline Married & 221 & 100.0 \\
\hline Single & 0 & 0.0 \\
\hline \multicolumn{3}{|l|}{ Family Size } \\
\hline$<5$ & 53 & 24.0 \\
\hline $5-14$ & 119 & 53.9 \\
\hline $15-24$ & 39 & 17.6 \\
\hline $25-34$ & 10 & 4.5 \\
\hline \multicolumn{3}{|l|}{ Mean Family Size $=9.8$} \\
\hline \multicolumn{3}{|l|}{ Educational Level } \\
\hline Secondary Certificate & 60 & 27.2 \\
\hline OND & 73 & 33.0 \\
\hline HND & 79 & 35.8 \\
\hline B.Sc./B.A. & 8 & 3.6 \\
\hline M.Sc./M.A. & 1 & 0.4 \\
\hline \multicolumn{3}{|l|}{ Work Experience } \\
\hline$<5$ & 41 & 18.6 \\
\hline $5-14$ & 20 & 9.0 \\
\hline $15-24$ & 117 & 52.9 \\
\hline $25-34$ & 43 & 19.5 \\
\hline \multicolumn{3}{|l|}{ Annual Income ( $\mathbf{N}$ ) } \\
\hline$<100,000$ & 1 & 0.4 \\
\hline $100,000-300,000$ & 135 & 61.1 \\
\hline $301,000-500,000$ & 45 & 20.4 \\
\hline $501,000-700,000$ & 9 & 4.1 \\
\hline $701,000-900,000$ & 12 & 5.4 \\
\hline $901,000-1,100,000$ & 3 & 1.4 \\
\hline$>1,100,000$ & 16 & 7.2 \\
\hline Mean Income $=\mathbb{3 7 6 , 9 8 4}$ & & \\
\hline
\end{tabular}

Field Survey, 2010 


\section{Awareness and access to ICTs}

The entire $(100 \%)$ extension agents were aware of radio, television and telephones as ICT tools (Table 2). Majority were also aware of DVD (99.1\%), camera (98.6\%), video $(98.2 \%)$, computer $(96.4 \%)$, printer $(95.9 \%)$ and the Web $(93.2 \%)$. Others were aware of satellite (92.8\%), e-mail (78.3\%), CD-ROM (69.2\%) and scanner (53.4\%). However, only $7.2 \%$ were aware of Web publishing, $25.3 \%$ of fax and $33.0 \%$ search engines. While Ani, (2007) recognized awareness as the first stage in adoption process, Agwu and Chah, (2007) observed that it is important to recognize that awareness among policy makers on the potentials of ICTs is a critical element for its development.

The entire extension agents (100\%) had access to radio while $99.1 \%$ had access to television, $98.2 \%$ telephone, $94.6 \%$ video, and $93.7 \%$ camera (Table 2 ). Others were $88.7 \%$ DVD, $85.5 \%$ computer, $78.7 \%$ printer and $68.8 \%$ satellite. The table indicates a low access to Web publishing (3.6\%), fax (7.7\%), scanner $(28.1 \%)$ and search engines (29.4\%). Others were The Web (37.6\%), CD-ROM (41.2\%) and E-mail $(46.2 \%)$. These findings supported the views of Omotayo (2005) that many rural areas of developing countries had no access to the basic telecommunication services that support key ICTs like the telephone and internet. 
Table 2

Awareness and access to ICTs

\begin{tabular}{llc}
\hline Variables & Frequency & Percentage $\mathbf{( n = 2 2 1 )}$ \\
\hline ICTs Awareness level & & \\
Radio & 221 & 100.0 \\
Television & 221 & 100.0 \\
Telephone & 221 & 100.0 \\
The Web & 206 & 93.2 \\
DVD & 219 & 99.1 \\
Video & 217 & 98.2 \\
Camera & 218 & 98.6 \\
Computer & 213 & 96.4 \\
Satellite & 205 & 92.8 \\
E-mail & 173 & 78.3 \\
CD-ROM & 153 & 69.2 \\
Printer & 212 & 95.9 \\
Search Engines & 73 & 33.0 \\
Scanner & 118 & 53.4 \\
Fax & 56 & 25.3 \\
Web Publishing & 16 & 7.2 \\
ICTs Access & & \\
Radio & 221 & 100.0 \\
Television & 219 & 99.1 \\
Telephone & 217 & 98.2 \\
The Web & 83 & 37.6 \\
DVD & 196 & 88.7 \\
Video & 209 & 94.6 \\
Camera & 207 & 93.7 \\
Computer & 189 & 85.5 \\
Satellite & 152 & 68.8 \\
E-mail & 102 & 46.2 \\
CD-ROM & 91 & 41.2 \\
Printer & 174 & 78.7 \\
Search Engines & 65 & 29.4 \\
Scanner & 62 & 28.1 \\
Fax & 17 & 7.7 \\
Web Publishing & 8 & 3.6 \\
\hline Field Survey, &
\end{tabular}

Field Survey, 2010

\section{Information and Communication Technology Use}

Table 3 shows that the entire extension agents (100\%) use radio while $99.6 \%$ use television, 98.2\% telephone, 92.3\% camera and 90.1\% DVD. Others were $80.1 \%$ video, $78.3 \%$ computer and $67.0 \%$ printer. There was however, a low usage of Web publishing $(0.5 \%)$, fax $(4.1 \%)$, and scanner $(10.9 \%)$. Others included CD-ROM $(21.3 \%)$, search engine $(30.8 \%)$, the Web $(31.2 \%)$, email $(37.1 \%)$ and satellite $(45.3 \%)$. It implies that majority of the extension agents had adopted one ICT or the other. According to Adeyinka, et al. (2009) since 2002, Nigeria has witnessed a rapid expansion of the internet. For instance, telephone lines in Nigeria prior to the introduction of the Digital Mobile Communications services popularly referred to as GSM in 2001 was mere 450,000 but increased to over 38 million lines by July 2007 thereby boosting teledensity growth from 0.4 to 24 . Elijah (2010) also reported that the internet has proved to be an invaluable resource for obtaining information and providing new dimensions to existing areas of business. For example, it enhances marketing of agricultural products through strengthening social networks and 


\section{Journal of Agricultural Extension}

Vol. 17 (1) June, 2013

ISSN 1119-944X

expansion of rural-urban linkages. Gelb et al. (2009) observed that adoption of ICTs as one instance of technological innovation dramatically improved the transfer and management of information, production chain efficiencies and integration within and with the agricultural sector. Lobo (2007) affirmed that multimedia communication campaigns were among the most effective methods of informing, training and diffusing appropriate technologies to farmers. Omotayo (2005) stated that a number of developments in many developing countries were shaping the future of extension services and setting the stage for the adoption of ICTs. According to Kiplang'at (2003) the impact of the use of ICTs in extension delivery still remained minimal as confirmed by a recent study to determine the diffusion of ICTs in communication of agricultural information among researchers and extension workers in Kenya.

\section{Table 3}

Information and Communication Technology Use

\begin{tabular}{lcc}
\hline Variables & Frequency & Percentage $\mathbf{( n = 2 2 1 )}$ \\
\hline Radio & 221 & 100.0 \\
Television & 220 & 99.6 \\
Telephone & 217 & 98.2 \\
The Web & 69 & 31.2 \\
DVD & 199 & 90.1 \\
Video & 177 & 80.1 \\
Camera & 204 & 92.3 \\
Computer & 173 & 78.3 \\
Satellite & 100 & 45.3 \\
E-mail & 82 & 37.1 \\
CD-ROM & 47 & 21.3 \\
Printer & 148 & 67.0 \\
Search Engines & 68 & 30.8 \\
Scanner & 24 & 10.9 \\
Fax & 9 & 4.1 \\
Web Publishing & 1 & 0.5 \\
\hline
\end{tabular}

Field Survey, 2010

\section{Types of Information Obtained and Disseminated Using ICTs}

Majority of the extension agents (64.0\%) obtained information on improved agricultural production techniques using ICTs (Table 4). Such information involves innovations on scientific production, new varieties of crops and livestock and their production techniques, modern bee keeping, irrigation or dry season farming scheme and fish farming techniques. Others include new fertilizer application technique, food and feed preservation, management of pests and diseases and the use of pesticides. They also obtained information on both improved production techniques, marketing and climate (13.8\%). Only $1.6 \%$ reported that they obtained information on 'others' using the ICTs. 'Others', refer to receiving and sending of mails and other messages such as those associated with staff meetings and training schedules, entertainment programmes such as music and drama, maps and results from workshops, seminars and conferences. This indicates that the ICTs were not optimally utilized by the extension agents in the extension activities, particularly concerned with communication. The result also reveals that most of the extension agents $(89.4 \%)$ disseminated information on improved production techniques to the farmers using ICTs. All the Information disseminated on improved production techniques were similar to those obtained using the ICTs. Similarly, only $1.1 \%$ of the extension agents disseminated other information described earlier as 'others', 


\section{Journal of Agricultural Extension}

Vol. 17 (1) June, 2013

ISSN 1119-944X

obtained using the ICTs (Table 4). However, they disseminated information on improved production techniques, marketing and climate (10.6\%). Marketing information involves the purchase of farm inputs and the prices of farm produce. Climate information entails the expected period of rain onset, planting and harvesting periods.

Table 4

\section{Types of Information Obtained and Disseminated Using ICTs}

\begin{tabular}{|c|c|c|}
\hline Variable & Frequency & Percentage \\
\hline \multicolumn{3}{|l|}{ Information Obtained Using ICTs $(n=189)$} \\
\hline Improved Production Techniques & 121 & 64.0 \\
\hline Marketing & 10 & 5.3 \\
\hline Climate & 3 & 1.6 \\
\hline Conservation & 2 & 1.1 \\
\hline Govt. Policies & 2 & 1.1 \\
\hline Others & 3 & 1.6 \\
\hline Improved Production Techniques and Marketing & 2 & 1.1 \\
\hline Improved Production Techniques and Climate & 5 & 2.7 \\
\hline Improved Production Techniques and Conservation & 2 & 1.1 \\
\hline Improved Production Techniques and Govt. Policies & 3 & 1.6 \\
\hline Improved Production Techniques, & 26 & 13.8 \\
\hline \multicolumn{3}{|l|}{ Marketing and Climate } \\
\hline $\begin{array}{l}\text { Improved Production Techniques, Marketing and } \\
\text { Conservation }\end{array}$ & 2 & 1.1 \\
\hline Improved Production & 8 & 4.2 \\
\hline Techniques and Others & & \\
\hline \multicolumn{3}{|l|}{ Information Disseminated Using ICTs $(n=189)$} \\
\hline Improved Production Techniques & 169 & 89.4 \\
\hline Marketing & 2 & 1.1 \\
\hline Climate & 4 & 2.2 \\
\hline Conservation & 6 & 3.2 \\
\hline Govt. Policies & 2 & 1.1 \\
\hline Others & 2 & 1.1 \\
\hline Improved Production Techniques \& Marketing & 4 & 2.2 \\
\hline Improved Production Techniques \& Climate & 7 & 3.7 \\
\hline Improved Production Techniques \& Conservation & 2 & 1.1 \\
\hline Improved Production Techniques \& Govt. Policies & 1 & 0.5 \\
\hline Improved Production Techniques, Marketing \& Climate & 20 & 10.6 \\
\hline
\end{tabular}

Source: Field Survey, 2010

\section{Correlation between Socio-economic Characteristics of Extension Agents and ICT Use}

Table 5 shows the correlation between the socio-economic characteristics of the extension agents and ICT use. Among the variables, age, years of working experience and membership of agricultural associations showed a positive correlation and therefore significantly $(p<0.05)$ related to ICT use. Similarly, education, annual income, ICTs training, awareness and access correlated positively and also significantly $(p<0.01)$ related to ICT use.

The result implies that with age and more years of working experience, an extension agent is expected to acquire more personal capital; hence, more capacity to 


\section{Journal of Agricultural Extension}

Vol. 17 (1) June, 2013

ISSN 1119-944X

purchase and use the ICT facilities. The more educated extension agents are more likely to adopt the ICTs for finding solutions to their professional and other problems. Increase in income improves the ICT purchasing power of the extension agent.

Table 5

Correlation between Socio-economic characteristics of Extension Agents and ICT use

\begin{tabular}{llll}
\hline $\begin{array}{l}\text { Dependent } \\
\text { Variable }\end{array}$ & $\begin{array}{l}\text { Independent } \\
\text { Variables }\end{array}$ & $\mathbf{R}-$ values & Sig. \\
\hline ICT use & Age & 0.156 & $0.05^{*}$ \\
ICT use & $\begin{array}{l}\text { Education } \\
\text { Years of work }\end{array}$ & 0.350 & 0.013 \\
ICT use & $\begin{array}{l}\text { Experience } \\
\text { Annual Income }\end{array}$ & $0.05^{*}$ \\
ICT use & Membership of & 0.134 & $0.01^{* *}$ \\
ICT use & Agric. Associations & $0.05^{*}$ \\
& ICTs Training & 0.190 & $0.01^{* *}$ \\
ICT use & ICTs Awareness 0.604 & $0.01^{* *}$ \\
ICT use & ICTs Access & 0.873 & $0.01^{* *}$ \\
ICT use & STignicant at $1 \%$ & &
\end{tabular}

${ }^{*}$ Significant at 5\% $\quad$ ** Significant at $1 \%$

\section{Conclusion}

ICTs are veritable tools for the formation of the needed linkages among researchers, agricultural extension agents and farmers. The benefits of the ICTs were not fully utilized by the extension agents in Kano State due to some factors associated with low income, ICTs training, awareness and access.

There is therefore the need for the development of ICTs infrastructure; especially in the rural areas to enable the extension agents have access to the key ICTs like telephone, computer and the internet.

\section{References}

Adebayo, E.L. and O.M. Adesope (2007). Awareness, access and usage of information and communication technologies between female researchers and extensionists. International Journal of Education and Development using ICT, 3(1):85-93.

Adedoyin, S.F.; O.E Fapojuwo, and D. Torimiro (1999). Educational Communication materials in Agric. Technology promotion: A survey of extension agents in ljebu area of Ogun State. Proceeedings of the fifth annual National Conference of the AESON 12th $-14^{\text {th }}$ April.

Adeyinka, T., N. Adetoro and P. A. Adekunle (2009): A case of Global System of Mobile Communication (GSM) in Nigeria. UPGRADE European Network, 10(2); April 2009.

Agwu, A. E. and J.M. Chah, (2007) Access and utilization of modern information 


\section{Journal of Agricultural Extension}

Vol. 17 (1) June, 2013

ISSN 1119-944X

communication technologies among extension personnel in Benue State of Nigeria. In: Madukwe, M. C (Ed.). Agricultural Extension and the Challenges of the Millennium Development Goals (MDGs). Proceedings of the 12th Annual Conference of the Agricultural Extension Society of Nigeria (AESON). Maiduguri, 4th $-7^{\text {th }}$ July.

Alampay, F. R. Heeks and , P.P.A Soliva. (2003). Bridging the information divide; A Philippine Guidebook on ICTs.

Amalu, U. (1998) Agricultural Research and Extension delivery systems in SubSaharan Africa . Calabar, University of Calabar Press.

Ani, A,O (2007). Agricultural Extension: A Pathway for Sustainable Agricultural Development. $1^{\text {st }}$ edition. Kaduna: Apani Publications, $179 \mathrm{pp}$.

Arokoyo, T. (2005). ICTs Application in Agricultural Extension Service Delivery. In: Adedoyin F.S. (Ed) Agricultural Extension in Nigeria. $1^{\text {st }}$ edition. Ilorin: AESON, Pp 245-251.

Asenso-Okyere, K. and D. A. Mekonnen (2012). The Importance of ICTs in the Provision of Information for Improving Agricultural Productivity and Rural Incomes in Africa. Working Paper; UNDP. 30pp

CTA (2003). ICTs- Transforming agricultural extension? An e-discussion, $20^{\text {th }}$ August-29 ${ }^{\text {th }}$ September.

Elijah, O.A. (2010). Effects of the Emerging Information Communication Technologies (ICTs) on Agricultural Knowledge Transfer to Smallholder Farmers in Nigehttp:/www.iimahd.ernet.in/egov/ifip/wg.htm. Cited on $10^{\text {th }}$ December, 2010.

FAO, (1993). The potentials of microcomputers in support of agricultural extension education and training. Rome, FAO.

Gelb, E., B. Gal, D. Wolfson (2009). Information and Communication Technologies (ICT) For Agricultural Extension - An Overtime Israeli Perspective.

Hosseini, S.J.F., M. Niknami and M. Chizari (2009). To determine the challenges in the application of ICTs by the agricultural extension service in Iran, Journal of Agricultural Extension and Rural Development, 1(1):27-30.

KNSG, (2004). Kano State Government Diary. Kano State, Nigeria.

Kiplang'at, J. (2003). Does Agricultural Extension have a new beginning because of ICTS? Reflection on experience in Sub-Saharan Africa. Keynote paper presented at the 6th consultative Expert Meeting on CTA's Observatory on ICTs. Wageningen September, $23^{\text {rd }}-25^{\text {th }}$.

Lobo (2007). Getting the Message Across with Multimedia. No. 128, 16pp. 


\section{Journal of Agricultural Extension}

Vol. 17 (1) June, 2013

ISSN 1119-944X

NPC (2006). Federal Republic of Nigeria Official Gazette, National Population Commission, 23(94).

Okunade, E.O. and Oladosu I.O. (2006). Rating of Extension Teaching Methods for Training Female Farmers in Osun state, Nigeria. Proceedings of $10^{\text {th }}$ Annual Conference of Agricultural Extension of Nigeria.

Olatokun, W.M. (2007). Availability, Accessibility and use of ICTs by Nigerian Women Academics, Malaysian Journal of Library \& Information Science,12(2): 13-33.

Omotayo, O.M. (2005). ICT and agricultural extension: Emerging issues in transferring agricultural technology in developing countries. In: Adedoyin S.F. (ed). Agricultural Extension in Nigeria. $1^{\text {st }}$ edition. Ilorin: AESON, pp 145-158.

Salau E.S. and N.D. Saingbe. (2008). Access and Utilization of Information and Communication Technologies(ICTs) Among Agricultural Researchers and Extension Workers in Selected Institutions in Nasarawa State of Nigeria. PAT 2008; 4 (2): 1-11. www.patnsukjournal.com/currentissue. Retrieved on 23rd January, 2011.

World Bank (2009), Report on, "Information and Communication for Development (IC4D) Extending Reach and Increasing Impact". Available on line at http://www.infodev.org/en/Article.384.html

Yakubu, D.H. (2011). Socio-economic factors affecting the Adoption of ICTs by ExtensionWorkers in the North-West zone of Nigeria. An M.Sc. Dissertation submitted to the Department of Agricultural Economics and Extension, Usmanu Danfodiyo University, Sokoto, 102pp. 